\title{
PROBLEMS OF TEACHERS' LABOUR RIGHTS IN REGIONS OF LATVIA
}

Anda Grinfelde ${ }^{1}$, Dr.oec.; Liga Paula ${ }^{2}$, Dr.sc.soc.; Ilze Prizevoite ${ }^{3}$, Mg.oec.

$1,2,3$ Latvia University of Life Sciences and Technologies

\begin{abstract}
The authors in the paper present some results of the study on teachers' labour rights, which was carried out in collaboration with the Latvian Trade Union of Education and Science Employees (LIZDA) from August until October 2017. The focus of the paper is on regional disparities regarding teachers' labour rights and the analysis of the teachers' opinions collected in the on-line survey. The aim of the research was to investigate, how teachers assessed their knowledge on the labour rights and protection of their rights in educational institutions as well as what are the problems in this field from the perspective of the teaching stuff. Two research questions are addressed in this paper: (1) what problems teachers face in relation to their labour rights in different regions of Latvia, and (2) what are possible solutions at institutional, municipal and the state levels to improve the protection of teachers' labour rights. The mixed method sequential explanatory research design was used in the study: firstly, the focus group discussion was organized with experts from the field of education; secondly, the quantitative survey of the teachers was conducted via web tool visidati.lv $(n=2055)$, and finally the panel discussion was organized to discuss the survey results and to seek proposals how to improve protection of the teachers' labour rights. The results witness about regional disparities and the fact that great part of the respondents does not feel protected when faces violation of their rights. However, many respondents reported on well-established practices in their schools, and support from administration and municipalities.
\end{abstract}

Key words: labour rights, teachers, educational institutions, regions, trade union.

JEL code: R23, K31

\section{Introduction}

Claiming on stronger protection of labour rights, F. Hendrickx, A. Marx, G. Rayp and J. Wouters emphasize that empirical research and studies witness both downward trend in labour rights protection around the world and the impact of the globalization of economic activities on labour rights (Hendrickx F., Marx A., Rayp G., Wouters J., 2016). Neo-liberal policies and economic crises force the governments to adopt decisions which in long-term negatively affect income and social security of workers (ETUCE, 2017) thus threatening stability of society and its middle class to which school teachers have traditionally associated with (Vaughan-Whitehead D., Vazquez-Alvarez R., Maitre N., 2016). In spite of governmental incentives to improve remuneration system and working conditions in rural and urban schools in Latvia, there is a still significant difference, for example, in salaries and workloads among regions what teachers consider as violation of their labour rights. Thus, the focus in the paper is on regional disparities regarding teachers' labour rights and the analysis of the teachers' opinions collected during teachers' survey in collaboration with the Latvian Trade Union of Education and Science Employees (LIZDA).

The mixed method sequential explanatory research design was used in the study comprising focus group discussion, quantitative survey and panel discussion. The aim of the research was to investigate, how teachers assessed both their knowledge on their labour rights and protection of the rights in their educational institutions as well as the problems in this field from the perspective of the teaching stuff. This paper seeks to answer two research questions: (1) what problems teachers face in relation to their labour rights in different regions of Latvia, and (2) what are possible solutions at institutional, municipal and the state levels to improve the protection of teachers' labour rights. Theoretical considerations of the research are based on the literature and studies on labour rights, teachers' rights and available statistics. 


\section{Research methodology}

To obtain empirical data, the mixed method sequential explanatory research design was employed (Creswell J. W., Plano Clark V. L., Gutmann M. L., Hanson W. E., 2003) with the following research stages: (1) the focus group discussion with eight experts from institutions related to education and policy making was organized on 17 August 2017; (2) the quantitative survey of the teachers $(n=2055)$ via web tool visidati.lv was conducted in September and October 2017; (3) the results of the survey were presented in LIZDA annual conference on 22 November 2017, which was concluded with the panel discussion on possible solutions to improve the protection of teachers' labour rights at institutional, municipal and the state levels. The web tool visidati.Iv was used as it was convenient for the respondents. During the focus group, the main problematic issues and risks related to the violations and insufficient protection of teachers' labour rights were identified. These conclusions and assumptions were turned into the statements, included in the survey, and assessed by the teachers using Likert scale. Information about the survey was disseminated in schools, via social media and web page eklase./v. The research sample was made of 2055 teachers from all statistical regions of Latvia (Zemgale, Vidzeme, Kurzeme, Latgale, Riga and Pieriga) representing all levels of general education including pre-school. 889 $(43.7 \%)$ respondents of the sample are teachers residing in cities, whereas 1157 or $56.3 \%$ of teachers are from rural municipalities including small towns. $94.8 \%$ or 1948 respondents are female and $5.2 \%(107)$ are male. Two-thirds (68\%) of the sample are in the age group between 40 to 59 years. $34 \%$ of the teachers have in-service experience in school over 30 years and for almost $30 \%$ of the respondents work experience in school is between 21 to 30 years. $66.9 \%$ of the sample are LIZDA members and few teachers - members of other trade unions whereas onethird of the respondents are not members of trade unions. SPSS software was used for the data analysis.

\section{Research results and discussion 1. Conceptualization of the teachers' labour rights}

Teachers are entitled the same fundamental labour rights as workers of other occupations. However, due to the specificity of their profession some specific rights need to be included. They are defined in the General Education Law (Visparigas izglitibas likums), in the Education Law and its Section 52 "Rights of Teachers" and Section 53 "Work Remuneration of Teachers" in particular (Izglitibas likums), and in the internal rules and regulations adopted in every educational institution.

There are supporters of opinion that labour rights (in other references - workers' rights) actually are human rights (for example, Gross A. J., 2006; Alston P. , 2005). Indeed, particular worker rights are already defined, for example, in the Articles 23, 24, and 25 of the Universal Declaration of Human Rights (United Nations General Assembly, 1948). Still, this opinion is not unequivocal and as V. Mantouvalou states "If labour rights are incorporated in human right documents, they are human rights" (Mantouvalou V., 2012, p. 151). In 1919, the International Labour Organization (ILO) was established to promote social justice. ILO's international labour standards are closely linked to the ILO's 1998 Declaration on Fundamental Principles and Rights at Work and state that all Members have an obligation to respect, to promote and to realize the principles concerning the fundamental rights that are:

(a) freedom of association and the effective recognition of the right to collective bargaining; 
(b) the elimination of all forms of forced or compulsory labour;

(c) the effective abolition of child labour;

(d) the elimination of discrimination in respect of employment and occupation (ILO, 2003).

Also, the Treaty of Rome (1957) referred to workers' rights "which obliged the European Communities Member States to promote the improvement of living and working conditions for workers, and required them to collaborate on a number of questions relating to employment" (Arrigo G., Casele G., 2005, p. 265). Latvia has developed its national legal framework and normative regulations in the respective field (Darba likums); it has also ratified 45 ILO Conventions, as well as both International Covenants and the European Convention on Human Rights (National Labour Law...). Latvia has ratified 25 Articles of the European Social Charter (Revised) (Council of Europe, 1996) and those related to the labour rights are presented in the Table 1. However, social partners in Latvia negotiate on ratifying also other Articles of the Charter which have not been ratified yet mostly due to their fiscal impact on the national budget.

Articles of the European Social Charter (Revised) ratified by the government of Latvia, 2017

\begin{tabular}{|c|c|}
\hline Articles & Title of the Article \\
\hline Article 2 & The right to just conditions of work \\
\hline Article 4 & The right to a fair remuneration (paragraphs $2,3,4$ and 5) \\
\hline Article 5 & The right to organise \\
\hline Article 6 & The right to bargain collectively \\
\hline $\begin{array}{l}\text { Article } \\
21\end{array}$ & The right to information and consultation \\
\hline $\begin{array}{l}\text { Article } \\
22\end{array}$ & $\begin{array}{l}\text { The right to take part in the determination and improvement of the working conditions and } \\
\text { working environment }\end{array}$ \\
\hline $\begin{array}{l}\text { Article } \\
26\end{array}$ & The right to dignity at work \\
\hline $\begin{array}{l}\text { Article } \\
\mathbf{2 8}\end{array}$ & $\begin{array}{l}\text { The right of workers' representatives to protection in the undertaking and facilities to be accorded } \\
\text { to them }\end{array}$ \\
\hline $\begin{array}{l}\text { Article } \\
29\end{array}$ & The right to information and consultation in collective redundancy procedures \\
\hline
\end{tabular}

In their study, B. Achinstein, R.T. Ogawa and A. Speiglman discuss that in socialization of new teachers, state educational policies, local district and school conditions interact with teachers' personal and professional backgrounds, even reinforcing educational inequalities (Achinstein B., Ogawa R.T., Speiglman A., 2004). D. Hill in his study analyses impacts of neo-liberalisation on education workers' securities (pay and salaries, conditions of employment, stresses and pressures at work, and their work identity and status) as well as on the rights and powers of education trade unions (Hill D., 2005). Due to economic crisis, policy makers in Europe favour quantitative adjustments such as cuts in public sector jobs and wages, and spending cuts, therefore, "employment security is no longer the norm in the public sector" (Vaughan-Whitehead D., Vazquez-Alvarez R., Maitre N., 2016, p. 31). This has direct impact on professionals from the public sector traditionally forming middle class, for example, teachers and doctors and their income and social security. As D. Vaughan-Whitehead, R. Vazquez-Alvarez and N. Maitre state (2016, p. 31), in education the process can be characterized by such indicator as higher ratios of teachers and students in classes; significant wage cuts often are due to a weakening of collective bargaining "through a number of reforms included on fiscal consolidation packages" (2016, p. 27). The 
authors also refer to limited collective bargaining in the Baltic States and Hungary (Vaughan-Whitehead D., Vazquez-Alvarez R., Maitre N., 2016, p. 43). It should be stressed here that the right to collective bargaining is one of the workers' fundamental rights.

Among OECD countries there are significant differences in remuneration of teachers, tasks and responsibilities teachers do, workloads (including amount of time that teachers spend for teaching and non-teaching activities), and respective policies (OECD, 2017). In 2017, UNESCO in relation to the World Teachers' Day called for greater attention towards teachers' academic freedom, decent working conditions for all teachers, and pointed that "across all education levels, political pressure and business interests can curb the ability of educators to teach in freedom" (UNESCO, 2017). Previous studies in Latvia show, that teachers in general are satisfied with particular aspects concerning their rights: the decision making process in schools is characterised as mostly democratic, teachers are satisfied with working conditions and the choice of the profession; however, teachers admit that their occupational status in a community is not high, and remuneration is low (Geske A., 2015; LIZDA, 2016), and their academic freedom and teacher autonomy are under pressure (LIZDA, 2016). Yet teachers report on inequalities and problems and this will be discussed further in the paper.

\section{Regional disparities: analysis of the research results}

Although there is a common methodology for calculating teacher's workload and remuneration, in reality it leads towards differences and inequalities among Latvian regions, municipalities and even within educational institutions in terms of how teachers are paid for teaching and no-teaching activities. Teachers treat this as a violation of their right to a fair remuneration. Due to global economic and financial crisis in 2008 having severe consequences in Latvian economy, the government introduced new model for financing general education "Money follows the student" (in Latvian - "Nauda seko skolenam") on the 1st of September 2009. That was governmental attempt to save public expenditure for education. In a result, the amount of the teacher's salary now greatly depends on a number of the students in school, which actually leads towards inequality when teachers for the same work in different municipalities receive different salary. Regional differences in teachers' salaries per one pedagogical rate in academic year 2017/2018 are presented in Figure 1.

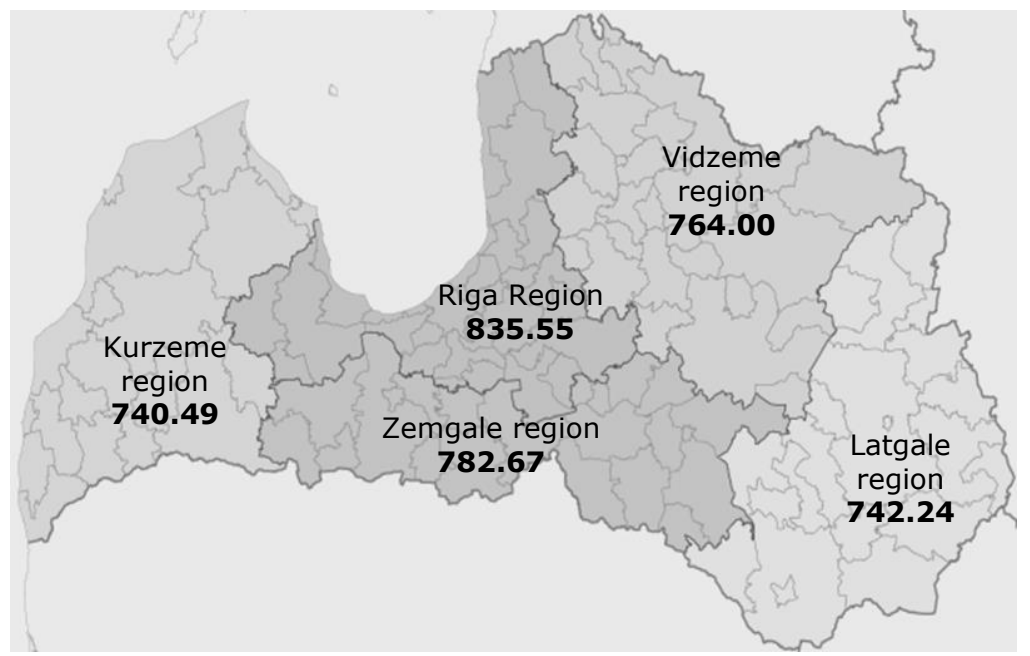

Source: authors' calculations based on VIIS data, 2017

Fig. 1. The average salary of teachers per one pedagogical rate in general education in the planning regions of Latvia 2017/2018, EUR 
The differences in average teachers' salaries in Latvian planning regions can reach up to $13 \%$. The highest average salaries teachers receive in Riga region (835.55 EUR), whereas in Kurzeme region - the lowest (740.49 EUR) due to great number of small rural schools with a small number of students. According to the current financing model, the small schools can afford only minimum for implementation of study programmes and lack resources to ensure teachers with adequate remuneration for non-teaching activities: correcting students' works, preparing for the lessons, and individual work with students. In 2016, an average salary in the public sector in Latvia was 885 EUR, but for workers in education - 703 EUR (Central Statistical Bureau, 2017). In academic year 2017/2018, an average salary for the teachers in general education is 772.99 EUR, which is still below the average in the public sector in 2016. In Latvia, there is no appropriate legal regulation on teachers' social guaranties to avoid introducing remuneration systems within educational institutions established by the state and municipalities which imply discriminating salary differences and inequalities. This raises great dissatisfaction among the teachers. Trade union members have reported on cases when, for example, technical staff members of a school received allowance in case of their relative death while teachers did not because officials from the Ministry of Education and Science stated that teachers were not entitled to receive support provided by the Law On Remuneration of Officials and Employees of State and Local Government. To avoid these situations, the solution is collective agreements comprising a norm entitling teachers social guarantees. However, collective bargaining in municipalities is often complicated thought it is a fundamental right of workers. Statistics about collective agreements in Latvian schools is presented in Table 2. Only $54 \%$ of 1161 trade unions in the educational institutions have managed to establish collective agreements.

Number of collective agreements in educational institutions in Latvia on $1^{\text {st }}$ of $^{\text {T }}$ January 2017

\begin{tabular}{|c|c|c|c|c|c|}
\hline \multirow{2}{*}{ Regions } & \multirow{2}{*}{$\begin{array}{l}\text { Number } \\
\text { of trade } \\
\text { unions }\end{array}$} & \multirow{2}{*}{$\begin{array}{l}\text { Number of } \\
\text { collective } \\
\text { agreements }\end{array}$} & \multirow{2}{*}{$\begin{array}{l}\text { Ratio of collective } \\
\text { agreements per } \\
\text { trade unions in } \\
\text { total, } \%\end{array}$} & \multicolumn{2}{|c|}{$\begin{array}{l}\text { Respondents' opinion about the } \\
\text { statement* "Teachers are always } \\
\text { duly introduced with changes in } \\
\text { collective agreements", \% }\end{array}$} \\
\hline & & & & $\begin{array}{c}\text { "Strongly } \\
\text { agree"; "slightly } \\
\text { agree" }\end{array}$ & $\begin{array}{c}\text { "Strongly } \\
\text { disagree"; } \\
\text { "slightly disagree" }\end{array}$ \\
\hline Riga & 213 & 45 & 21 & 60 & 12 \\
\hline Pieriga & 188 & 147 & 78 & 72 & 8 \\
\hline Vidzeme & 206 & 115 & 56 & 70 & 9 \\
\hline Kurzeme & 191 & 114 & 60 & 68 & 10 \\
\hline Zemgale & 154 & 75 & 49 & 74 & 11 \\
\hline Latgale & 209 & 136 & 65 & 80 & 5 \\
\hline In total & 1161 & 632 & 54 & $\begin{array}{l}\text { Average in } \\
\text { Latvia: } 71\end{array}$ & $\begin{array}{l}\text { Average in Latvia: } \\
\qquad 9\end{array}$ \\
\hline
\end{tabular}

Source: Authors' calculations based LIZDA data and LIZDA survey data*

Approximately two-thirds of the respondents agree that teachers are always duly introduced with changes in the collective agreements (Figure 2). 


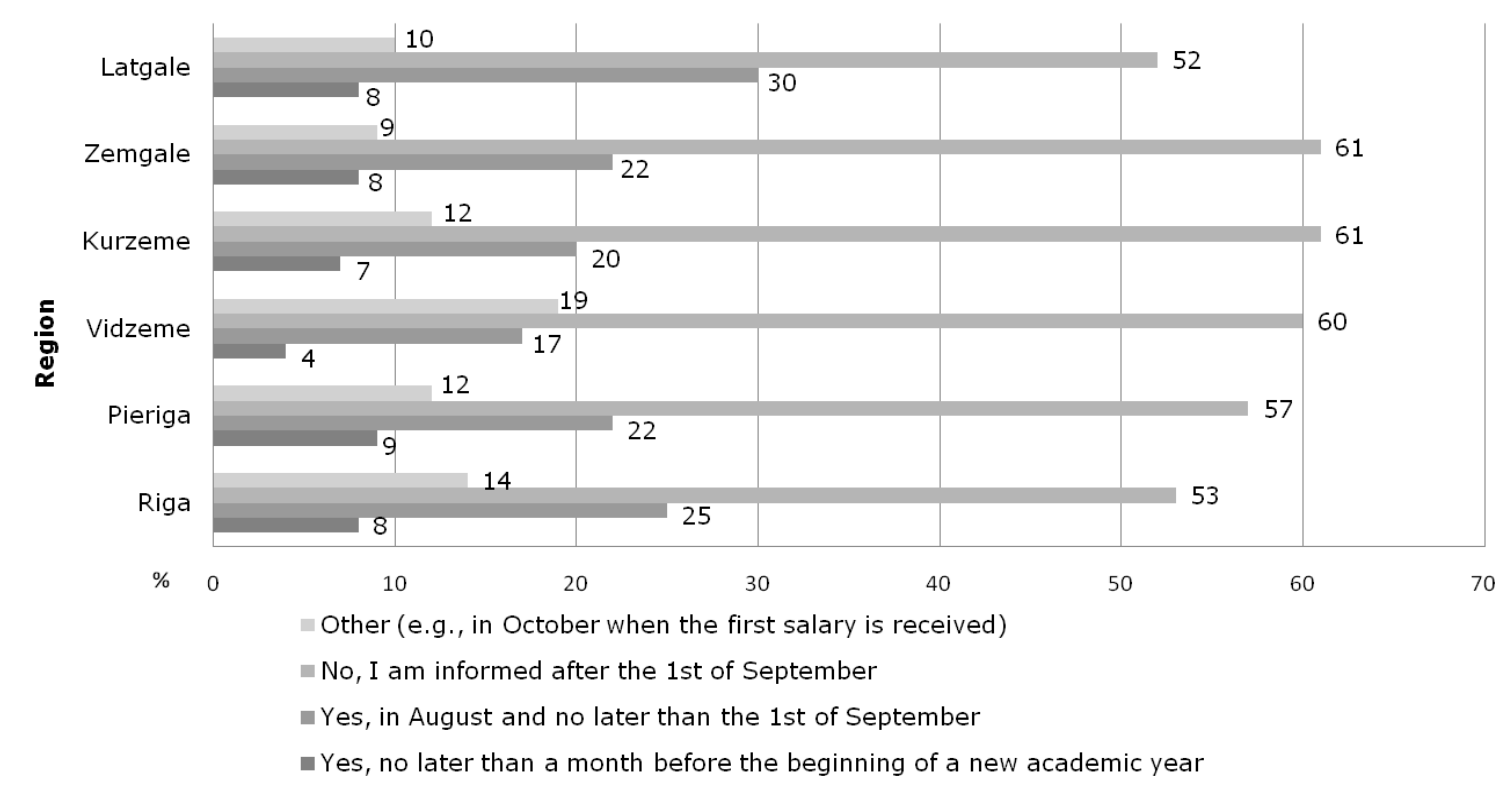

Source: Authors' calculations based LIZDA survey data

Fig. 2. Teachers' views on availability of duly information about their salary $(\%), \mathbf{n = 2 0 5 5}$

To compare the answers between the regions, teachers in Latgale (80\%) are more positive about this in comparison with their colleagues in Riga (60\%). It should be emphasized also that the number of collective agreements in Riga is the smallest among the regions. Still, almost halve of the respondents from Riga and Latgale and around $60 \%$ in other regions learn about the amount of salary after the $1^{\text {st }}$ of September, which is a violation of legal norms. Teachers in Latvia believe that their occupational status is low. Eight teachers of ten believe that occupational status has impact on public attitude towards teachers' rights. There are no significant differences in opinions about this statement among the regions; however, slightly less positive are respondents in Kurzeme (77.2 \%) and Latgale (74.6 \%). Data in the Figure 3 show that teachers almost do not feel the pressure from the school directors in the context of their rights; only $27 \%$ are positive. $58 \%$ respondents in Latgale, but $49 \%$ in Vidzeme believe that their professional autonomy is under the threat.

In comparison to other regions, teachers in Latgale (58\%) feel more restricted in terms of their rights from the side of parents. In general, problematic fact is that teachers feel too much controlled (69\%) and afraid to report on violations of their rights as do not believe that they will receive support $(71 \%)$. This is obvious in case of Latgale region whereas teachers in Zemgale more than in other regions afraid to make decisions or choices in order to avoid breaking rules. Alarming is the fact that approximately $80 \%$ of the respondents admit that they feel insecure in terms of protection their rights. To conclude, teachers in Latgale point greater risks in protection their rights as respondents from other regions, especially Riga and Pieriga. To sum up, during the panel discussion at LIZDA annual conference the following solutions were defined (Table 3). 
Teachers afraid to report on violations of their rights as they are confident that they will be not supported

Teachers try to avoid making decisions or choices because they afraid to violate legal norms

Teachers often feel insecure about the protection of their rights

Teachers shoud raise their self-awareness in order to stand for their rights

Director of the educational institution makes pressure on teachers within a context of labour rights

In educational institutions teachers feel that their rights are curbed by the parents of the students

In general, teachers' work is controlled to much

Teachers' professional authonomy is thretned
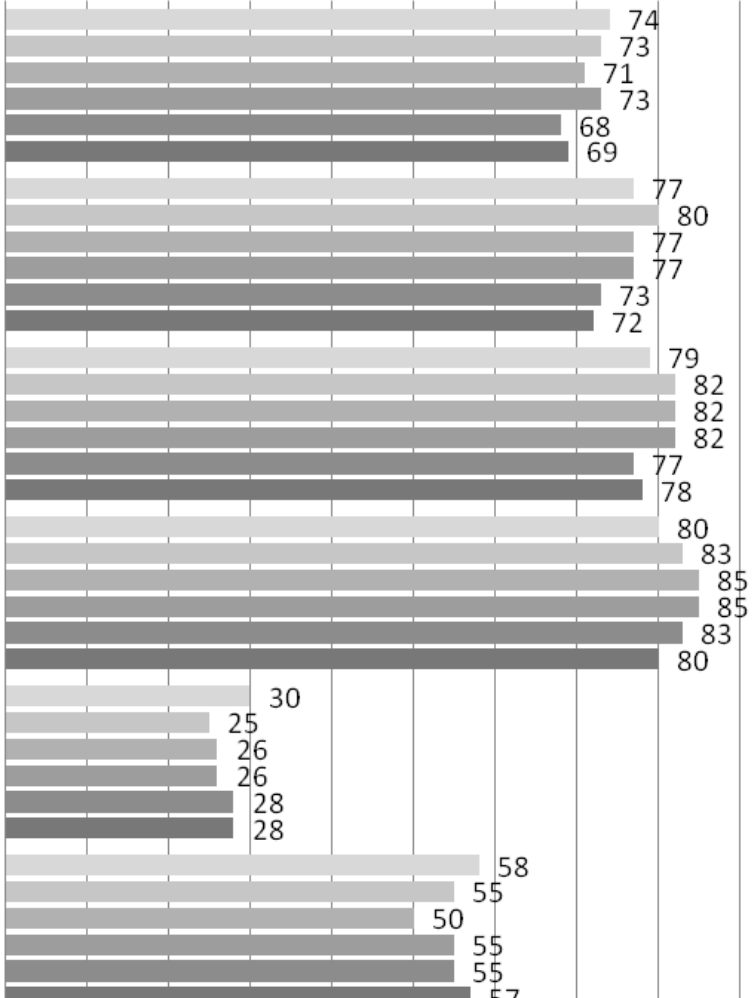

55

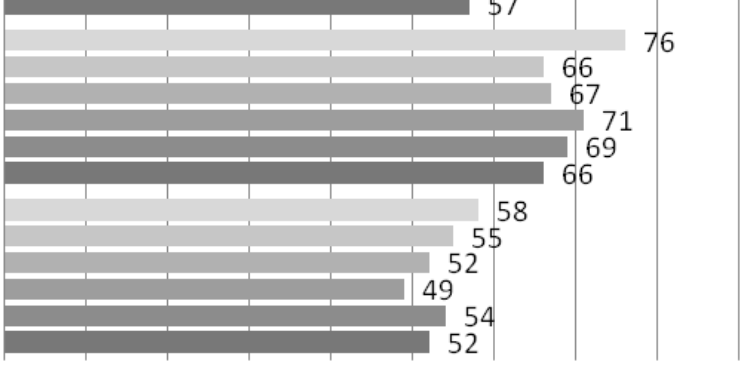

$\begin{array}{lllllllll}0 & 10 & 20 & 30 & 40 & 50 & 60 & 70 & 80\end{array}$

Latgale $\square$ Zemgale $\square$ Kurzeme $\square$ Vidzeme $\square$ Pieriga $\square$ Riga

Source: Authors' calculations based LIZDA survey data

Fig. 3. Teachers' opinions about the statements (aggregate of choices "strongly agree" and "slightly agree" ( \%), n=2055)

It should be noted that some proposals seem to be more emotional rather than rational; however, they well reflect teachers' attitudes and needs for particular support in protection their rights. 
How to improve protection of teachers' labour rights: proposals of the LIZDA panel discussion

\begin{tabular}{|l|l|l|}
\hline \multicolumn{1}{|c|}{ Education institution } & \multicolumn{1}{|c|}{ Municipality } & \multicolumn{1}{c|}{ The State } \\
\hline $\begin{array}{l}\text { More teachers should join the } \\
\text { trade unions as more powerful } \\
\text { unions can attain compliance } \\
\text { with the teachers' labour rights } \\
\text { in educational institutions }\end{array}$ & $\begin{array}{l}\text { To draw more attention of a } \\
\text { society and local community } \\
\text { on protection of teachers' } \\
\text { rights }\end{array}$ & $\begin{array}{l}\text { To state by the rules of the Cabinet } \\
\text { of Ministers that tariffication of } \\
\text { teachers should be conformed with } \\
\text { a trade union mandatory and both } \\
\text { pedagogical rates and salaries } \\
\text { should be transparent for all } \\
\text { teachers in school }\end{array}$ \\
\hline $\begin{array}{l}\text { Seminars on protection of labour } \\
\text { rights should be organized for } \\
\text { teachers to be educated how to } \\
\text { proceed in cases of violation of } \\
\text { their rights }\end{array}$ & $\begin{array}{l}\text { To ensure adoption of } \\
\text { remuneration schedule and its } \\
\text { consistent implementation }\end{array}$ & $\begin{array}{l}\text { Controlling bodies should be more } \\
\text { opened to consultations and support } \\
\text { instead of punishing }\end{array}$ \\
\hline $\begin{array}{l}\text { To ensure teachers with } \\
\text { opportunities to receive } \\
\text { consultations of a lawyer who is } \\
\text { competent in specificity of a } \\
\text { teaching profession }\end{array}$ & $\begin{array}{l}\text { Duly introduce teachers with } \\
\text { respective legal norms and } \\
\text { their changes }\end{array}$ & $\begin{array}{l}\text { Specific instrument should be } \\
\text { developed to punish students and/or } \\
\text { their parents in order to protect } \\
\text { teachers from false accuses }\end{array}$ \\
\hline $\begin{array}{l}\text { To investigate each conflict and } \\
\text { dispute from all sides, } \\
\text { organizing independent } \\
\text { committee of specialists if } \\
\text { necessary }\end{array}$ & $\begin{array}{l}\text { To publish on the websites of } \\
\text { municipalities principles of } \\
\text { distribution workloads and } \\
\text { earmarked subsidies }\end{array}$ & $\begin{array}{l}\text { To control that mass media provide } \\
\text { only secure and true information } \\
\text { thus avoid cases of touching } \\
\text { teacher's dignity }\end{array}$ \\
\hline $\begin{array}{l}\text { To avoid teachers' overwork in } \\
\text { order to respect their rights on } \\
\text { privacy and rest }\end{array}$ & $\begin{array}{l}\text { To ensure equal attitude } \\
\text { towards teachers of all } \\
\text { schools especially in cities } \\
\text { with many schools }\end{array}$ & $\begin{array}{l}\text { To stop abusing education system, } \\
\text { competences and teachers and level } \\
\text { of student knowledge }\end{array}$ \\
\hline
\end{tabular}

Source: panel discussion in annual LIZDA conference, November 22, 2017

\section{Conclusions}

1) Neo-liberal policies and economic crises force the governments across the Europe including Latvia to adopt decisions which negatively affect income and social security of workers in the public sector. Cuts in public expenditure and jobs in education have impact also on the quality of teaching.

2) Collective bargaining practices in Latvia vary among municipalities and a number of the collective agreements in educational institutions is not high. Data show that the teachers' right to receive equal pay for the same job is violated even within boundaries of the same municipality. In the survey, problem with duly information on pedagogical rate and salary is the most frequently reported violation of teachers' rights. Other problems reported by teachers are lack of support from the administration and municipalities in protection of teacher's rights, insecurity about their rights and fear to make wrong decisions which later will be translated as exceeding teacher's authority. This is due to lack of self-confidence and knowledge about teachers' rights as well as often observed pressure from, for example, parents of the students.

3) Based on the research results solutions for improvements in protection of teachers' rights were formulated to be implemented by the education institutions, municipalities and the State.

\section{Bibliography}

1. Achinstein, B., Ogawa, R. T., Speiglman, A. (2004). Are We Creating Separate and Unequal Tracks of Teachers? The Effects of State Policy, Local Conditions, and Teacher Characteristics on New Teacher Socialization. American Educational Research Journal, Volume 41, Issue 3, pp. 557-603.

2. Alston, P. (2005). Labour Rights as Human Rights. Oxford: Oxford University Press, p. 253. 
3. Arrigo, G., Casele, G. (Eds.) (2005). Glossary on Labour Law and Industrial Relations. Geneva: International Labour Office, p. 278. Retrieved: http://www.ilo.org/wcmsp5/groups/public/---ed_dialogue/--lab_admin/documents/publication/wcms_113920.pdf Access: 30.01.2018.

4. Creswell, J. W., Plano Clark, V. L., Gutmann, M. L., Hanson, W. E. (2003). Advanced Mixed Methods Research Designs. In A. Tashakkori, C. Teddlie (Eds.) "Handbook of Mixed Methods in Social and Behavioral Research", Thousand Oaks, CA: Sage. pp. 209-240.

5. Council of Europe (1996). European Social Charter (Revised). Retrieved: https://rm.coe.int/168007cf93 Access: 04.02.2018.

6. Central Statistical Bureau. Retrieved: http://www.csb.gov.Iv/en/dati/data-23959.html Access: 05.02.2018.

7. Darba likums (Labour Law). Retrieved: https://likumi.lv/doc.php?id=26019 Access: 30.01.2018.

8. Geske, A. (Ed.) (2015). Skolotaji Latvija un pasaule (Teachers in Latvia and Around the World). Riga: LU PPMF Izglitibas petniecibas instituts, p. 293. Retrieved: http://sf.viaa.gov.Iv/library/files/original/SkolotajiLatvijaUnPasaule.pdf Access: 30.01.2018.

9. ETUCE (2017). Pay in the Public Services - How Workers Continue to Pay for the Crisis. Briefing paper. Retrieved: https://www.csee-etuce.org/images/CALLS/EPSU-ETUCE_Briefing_Pay_in_the_Public_Sector.pdf Access: 04.02.2018.

10. Gross, A. J. (2006). Workers' Rights as Human Rights. Ithaca: Cornell University Press, p. 272.

11. Hendrickx, F., Marx, A., Rayp, G., Wouters, J. (2016). The Architecture of Global Labour Governance. International Labour Review, Volume 155, Issue 3, pp. 339-356.

12. Hill, D. (2005). Globalisation and Its Educational Discontents: Neoliberalisation and its Impacts on Education Workers' Rights, Pay and Conditions. International Studies in Sociology of Education, Volume 15, Issue 3, pp. 257-288.

13. ILO (2003). Fundamental Rights at Work and International Labour Standards. Geneva: ILO, p. 140. Retrieved:

http://www.ilo.org/wcmsp5/groups/public/@ed_norm/@normes/documents/publication/wcms_087424.pdf Access: 30.01.2018.

14. Izglitibas likums (Education Law). Retrieved: https://likumi.Iv/doc.php?id=50759 Access: 04.02.2018.

15. Latvian Trade Union of Education and Science Employees (2017). Unpublished statistics and annual reports.

16. LIZDA (2016). Skolotaja profesijas prestizs Latvija: Parskats par LIZDA interneta aptaujas rezultatiem (Occupational Prestige of the Teaching Profession in Latvia: Overview of LIZDA on-line survey). Retrieved: http://www.lizda.Iv/content/files/LIZDA_aptauja-publikacija-15-11-2016.pdf Access: 04.02.2018.

17. Mantouvalou, V. (2012). Are Labour Rights Human Rights? European Labour Law Journal, Volume 3, Issue 2, pp. 151-172.

18. Nacionalas trispusejas sadarbibas padomes Socialas drosibas apakspadomes (SDA) sanaksmes protokols Nr.5, 2017. gada 18. oktobri (Minutes No 5 of the National Tripartite Cooperation Council, Social Security Subcouncil, 18th October, 2017). Retrieved: http://www.Im.gov.Iv/upload/protokols/prot_nr5_181017.pdf Access: 5.02.2018.

19. National Labour Law Profile: Latvia. Retrieved: http://www.ilo.org/ifpdial/information-resources/nationallabour-law-profiles/WCMS_158912/lang--en/index.htm Access: 23.01.2018.

20. OECD (2017). Education at a Glance 2017: OECD Indicators. Paris: OECD Publishing, p. 453.

21. The Treaty of Rome (1957). Retrieved: https://ec.europa.eu/romania/sites/romania/files/tratatul_de_la_roma.pdf Access: 30.01.2018.

22. UNESCO (2017). Joint Message on the Occasion of World Teachers' Day 2017: Teaching in Freedom, Empowering Teachers. Retrieved: http://unesdoc.unesco.org/images/0025/002592/259268e.pdf Access: 23.01.2018.

23. United Nations General Assembly (1948). Universal Declaration of Human Rights. Retrieved: http://www.un.org/en/universal-declaration-human-rights/ Access: 30.01.2018.

24. Valsts izglitibas informacijas sistema (VIIS) (The State Education Information System). Retrieved: https://www.viis.Iv Access: 04.02.2018.

25. Vaughan-Whitehead, D., Vazquez-Alvarez, R., Maitre, N. (2016). Is the World of Work Behind Middle-Class Erosion? In D. Vaughan-Whitehead (Ed.) "Europe's Disappearing Middle Class? Evidence from the world of work". Geneva, Cheltenham: International Labour Office, Edward Elgar. pp. 1-61.

26. Visparejas izglitibas likums (General Education Law). Retrieved: https://likumi.lv/doc.php?id=20243 Access: 04.02.2018. 